\title{
Mapping the Obama administration's response to the Arab Spring
}

\author{
A evolução da resposta da Administração Obama \\ à Primavera Árabe
}

MARIA DO CÉU DE PINHO FERREIRA PINTO*

Rev. Bras. Polít. Int. 55 (2): 109-130 [2012]

\section{Introduction}

Since January 2011, popular uprisings overthrew the long-time dictators of Tunisia and Egypt. They shook rulers in Libya, Bahrain, Syria, Yemen, Morocco, and Jordan, marking it the greatest wave of political unrest the world has seen since the fall of the Berlin Wall. This paper will try to map the US reaction to the unexpected events of the Arab Spring and how it put together a policy response. It will start with an introduction presenting a framework for the understanding of the policy approach of the Obama administration during the first months of the Arab uprisings. Then, it will map the evolution of the US policy toward the events in the different Arab Spring countries, especially Egypt, Libya, Bahrain, Yemen, and Syria. The aim is to appraise namely whether the regime changes brought about a reassessment of American foreign policy, shifting from decades of support for autocratic regimes to backing for pro-democracy movements.

\section{Trying to frame a policy approach}

The Obama administration's response to the Arab Spring has been fairly ambivalent and hesitant. Indeed, the apparent inconsistencies of US policy visà-vis the Arab Spring (for example, calling for Hosni Mubarak's departure just days after Cairo's street protests took shape, while refusing to denounce the Bashar al-Assad's regime in Syria despite weeks of protests and repression), combined with a determination to a forceful regime change in Libya, only highlighted the contrast between the administration's determined approach toward some of the Arab Spring regimes and much of the rest of its Middle East policy.

\footnotetext{
* Faculty member at Universidade do Minho's School of Economics and Management at the Department of International Relations and Public Administration (mceupinto@gmail.com).
} 
Critics have faulted the US for its seemingly embrace of the concept of "responsibility to protect" in Libya and calling for Col. Muammar Gadhafi to step down from power and not defending the same in Syria. The approach toward Syria contrasts markedly with military intervention in Libya or the US stance toward the brutal crackdown of pro-democracy protesters in Bahrain - a tiny, but strategic US ally in the Persian Gulf. The uprising against the minority dictatorship in Bahrain was largely ignored by Washington, which fears losing the headquarters of its Fifth Fleet in Manama. When Saudi tanks crossed the bridge to crush the Shia uprising in Bahrain, in March 2011, Obama kept silent and reluctantly acquiesced not wanting to alienate Riyadh.

The administration was also criticized for being too cautious in offering support to protesters in Cairo in the first weeks of the revolt. Eventually, the administration managed to sharpen the message and to try to place itself "on the right side of history," but at the cost of dumping a valuable ally. Still, others especially Republicans, including presidential candidates - slammed the Obama administration's support for the Arab Spring for foolishly opening the door to Islamist takeovers of once secular governments.

After siding reluctantly with the people's revolutions in Tunisia and Egypt against pro-American regimes, Obama has reportedly reverted to Washington's old double standard of shielding friendly authoritarian regimes in the Muslim world. Obama seems to have adopted the same strategic calculus as previous administrations: where compelling economic, energy or security interests are at stake, autocrat regimes are allowed not to be scrutinized by their democracy and human rights record.

The administration's cautious response to the popular uprisings across the Middle East and North Africa is the reflection of a realist policy driven by strategic interests, such as oil security, fighting terrorism, Iran's rise in the region and, equally important, its realization of the limits of American power and its capacity to shape events.

The Obama administration eventually concluded that it must shape its response country by country, recognizing a stark reality that American national security interests in the Middle East weigh as heavily as idealistic impulses.

\section{US interests in the Middle East in a historical perspective}

The dominant concern of American foreign policy in the post-World War II period was finding effective ways to check Soviet expansionism. When applied to the Middle East, this meant using all means available to prevent the Russians from filling the power vacuum being created by gradual withdrawal of old colonial powers. The interrelated objectives of containing Soviet attempts to gain the upper hand in the area and preserving access to the region's strategic facilities and oil resources required the development of effective doctrines and policies to attain the 
designated goals, namely the promotion of peace and stability and the recruitment of regional partners to assist the United States in containing the Soviet Union. The first orientation consisted in guaranteeing the territorial status quo and keeping the established political order in place as much as possible. Other major interests were to assure the survival and security of Israel and termination of the Arab-Israeli conflict (Lenczowski 1992).

American steadfastness reflected a definite conception of the importance of the Middle East itself to the United States. The protection of the oil resources in the Middle East, and the respective lines of communication, would remain a vital Western interest and would determine the US strategy and military deployments throughout the subsequent decades (Lesser 1992, 25).

By the 1950s, the emerging Arab nationalist movement became an additional (and most likely) danger to US hold over the oil resources of the region (Campbell 1969, 257). Local disputes and radical processes of change were considered to provide appropriate grounds for communist/Soviet-sponsored activity. US policy was thus guided by the basic conviction that radicalizing political tendencies of any sort would challenge Western-favored access to cheap and reliable supplies of oil, the very key to the economic growth of the industrialized world. US opposition to the nationalist movement had an early manifestation in Iran, when in 1953 the Central Intelligence Agency (CIA) executed a plan to overthrow the nationalist Prime Minister, Mohammed Mossadegh, in order to thwart the nationalization of the oil sector. Another tangible display of this concern was US policy to integrate the region in its global system of alliances and to preempt a possible shift by a regional state away from the American orbit. The US support to "moderate," pro-Western regimes in the Middle East (Egypt, Jordan, Lebanon), contemplating also the most important oil producers (Gulf kingdoms, Saudi Arabia, and Iran), was largely successful.

In the wake of the Iranian revolution (1979), the rising political power of Muslim fundamentalism became a new prominent threat. It was only after the Iranian Revolution with its follow-up of fiery, revolutionary Islamist-sponsored turmoil, that political Islam's strength was properly considered. The Iranian revolution and the wave of Shiite radicalism that marked the 1980s contributed, in another important way, to the shaping in the West of a stereotyped image of political Islam: that of an anti-democratic, anti-Western force. With the demise of communism and the end of the Cold War, a current of thought emerged saying political Islam is the new threat that confronts the West. Many saw it as aggressively anti-Semitic and anti-Western and charged Islamist movements of standing in direct competition to Western civilization and challenging it for global supremacy (Pinto 1999).

Growing American fears about political Islam are played into the hands of US allies, such as in the case with Egypt, Saudi Arabia, Turkey, and Pakistan. The 'political Islam menace became a convenient way for a leader to explain away 
opposition based on a country's economic, social, and political inequities. It was also an argument in favor of the continuation of US support to regimes whose strategic value weakened with the end of the Cold War.

In the 1990s, an additional interest was added to the three core ones: reducing the threats posed by so-called rogue states, particularly those aiming to acquire weapons of mass destruction. In response to the September 11 attacks, the Bush administration adopted three major policies to advance US national security interests in the region: defeating terrorism, promoting democracy, and stopping the development of weapons of mass destruction (Pressman 2009).

\section{The Arab Spring and political change in Tunisia and Egypt}

In response to the events of the Arab Spring, the Obama administration has assumed different policy approaches. They are situated along a nuanced line that goes from favoring drastic regime change (whether peacefully or by force), in some cases, and nudging other regimes towards gradual democratic transformation. These approaches will be briefly outlined in the following paragraphs.

In Egypt and Tunisia, Obama chose to rebalance the American stance, gradually backing away from support for Mubarak and Zine El Abidine Ben Ali and allowing the popular movements to run their course.

In Tunisia, the act of despair of one fruit vendor unleashed a wave of revolution through the Arab world. The protests were sparked by the selfimmolation of Mohamed Bouazizi on December 17, 2010, and led to the ousting of President Ben Ali, 28 days later, on January 14, 2011, putting an end to 23 years of autocratic rule. The popular rebellion that started there spread to Egypt, Libya, and then on to the Persian Gulf and the Near East.

In the first months of the uprisings, Obama's cautious response to the popular uprisings across the Middle East and North Africa drew frequent criticism. It wasn't until May that Obama firmly put the US on the side of Arab reform during his speech delivered at the State Department. However, the first clear instance was Tunisia, where Obama immediately clearly chose to back away from support for Ben Ali.

Obama expressed his support for the Tunisian pro-democracy movement saying: "the United States of America stands with the people of Tunisia, and supports the democratic aspirations of all people" (CBSNews 2011). However, in the following weeks, the administration voiced its concern for the transition process in that country: "But there's a long way to go. But, there's no experience. There's no institutional muscle memory about how you do this" (US State Department 2011).

In Egypt, the willingness of the Obama administration to break with the existing order and embrace its radical transformation was only too equivocal. The 
administration tried to perform a high-wire act between positioning itself "on the right side of history," as one senior diplomat put it, and not unceremoniously dumping a leader who has supported American policy on key regional policies (Miller 2011). The balancing act performed by the Obama administration regarding the approach to adopt towards the Mubarak regime became excruciating to watch as the former tried to balance conflicting orientations. As a result, the message often sounded muddled, as if written on an improvised playbook.

\section{Procrastinating in Egypt}

Egypt's revolution began on January 25, the "Day of Revolt," when tens of thousands of marchers occupied Cairo's Tahrir Square to protest against President Mubarak and his government. Probably, not enough information was available to high-level policymakers at least by late January 2011 to have moved the Obama administration to seriously examine the possibility of profound instability for the one-man government in Egypt. To be true, the administration's concern with the evolving revolt was uttered by Secretary of State, Hillary Clinton, during a speech at the Forum for the Future conference in Doha, on January 13 (Clinton 2011). The secretary of state's speech actually marked a pronounced contrast with the tone of the Obama administration so far. In point of fact, President Obama had been criticized by democracy activists for not more aggressively pushing leaders in the Arab and Muslim world to pursue political openness. Secretary Clinton warned Arab governments that they risked "sinking into the sand" if they did not meet the needs of their people in terms of democratization and development. That reaction signaled the US frustration with the lack of political change, undermining efforts to create stable Arab governments that can effectively combat terrorism.

In any case, the outbreak of the revolution caught Washington by surprise and constituted a significant intelligence failure. This event was similar to a certain extent to Washington's unpreparedness towards the 1979 revolution in Iran. Back then, not only did the administration fail to prevent the traumatic collapse of Pahlavi rule, which damaged the power and credibility of the United States in this critical part of the world, and, perhaps more importantly, undermined the prospects of constructive US-Iranian relations up to the present time. The belief that the Shah would remain in power despite the wave of protest was the prevailing view of the Carter administration and the possibility that he might be forced out of office as a result of the crisis was dismissed (Pinto 1999, 52). In December 1977, during a visit to Tehran, and as the police charged the demonstrations against his visit, Carter had referred to Iran as "an island of stability in a turbulent corner of the world" (Bill 1998, 233). Later President Carter would express his "dissatisfaction with the intelligence community failure to warn the administration of the political crisis in Iran" (Brzezinski 1983, 367). 
In the early weeks of the crisis, the majority of Washington's political establishment believed in Mubarak's resilience, as no one in the bureaucracy wished to be the first to "make the call" that the Rais ${ }^{1}$ was on his way out. Similarly as with the Iranian revolution, as a consequence, each individual and each organizational element procrastinated, waiting for incontrovertible evidence before pronouncing such a fateful judgment (Sick 1985, 42). In the aftermath of the "Day of Rage," the first crucial day of the protests in Egypt, Clinton offered a flimsy reaction of the Mubarak's government hold on power. She gauged it was "stable" and was responding to "the legitimate needs and interests of the Egyptian people" (Sanger 2011). Hours later, riot police attacked the thousands of demonstrators who had gathered in Tahrir Square.

Drawing a parallel to the Carter administration failure regarding the Iranian revolution, Gary Sick explains that Washington's inactivity and inability to draw the proper conclusions from revolutionary events has to do with "the paralysis of bureaucratic structures in high-risk situations" (Sick 1985, 42). He argues that if the revolutionary events had taken place in an area of the world with less strategic importance, there would have been "little reluctance to speculate about a range of possible outcomes, including revolutionary overthrow of the existing power structure" (Sick 1985, 42).

From the "Day of Rage" on, the administration frantically tried to catch up with events, and at last begun to adjust its policy to the fast changing events. On January 26, Hillary Clinton urged all parties "to exercise restraint" (Clinton 2011), while also appealing to the Egyptian authorities to allow peaceful protests and the use of the social media. By the end of January, Obama sent former US Ambassador to Egypt, Frank Wisner, to convince Mubarak not to seek another term and to help Egyptian officials plan elections for autumn. On February 1, in a televised address, Mubarak defied demonstrators who wanted him to leave immediately, by announcing he would not seek re-election, but would serve out the rest of his term until September. The statement forced Obama into a difficult position. The official policy of support for Mubarak was bent on the assumption that the he was capable of acting vigorously and decisively and that events would not get out of hand: that was an expectation that proved to be unfounded and short-lived. Obama's reaction was that "an orderly transition must be meaningful, it must be peaceful, and it must begin now" (Dorning and Goldman 2011).

Obama's statement entered a new phase with Obama's carefully nuanced public statements signaling a desire for Mubarak to step aside. The announcement went a long way to meeting pressures for him to make clear his support for the protesters and preparing the way for easing Mubarak out of the way as painlessly as possible while beefing up the position of the moderate opposition. On behest of the administration, Admiral Michael Mullen, the chairman of the US Joint

1 In Arabic, it means "President." 
Chiefs of Staff, quietly pressed the newly designated Egyptian Vice President, Omar Suleiman, to urge Mubarak to step aside so that he could begin negotiating a transition to a new government with a coalition of opposition figures, including the Muslim Brotherhood (Miller 2011).

The White House had clearly decided that the Rais' departure would enhance the chances that other figures in the regime, such as Gen. Omar Suleiman, could negotiate a smooth transition. The administration apparently concluded that stability could only be restored quickly in Egypt if it entered a smooth transition period. US officials feared that protests rocking Egypt could change the political landscape of the entire Arab world and beyond. Possible outcomes could range all the way from pro-democracy forces taking charge in Cairo to, in a worst-case scenario, regional war and instability, involving Israel and Iran. In between, there could be a long period of instability that could breed economic chaos across the region, prolonging the economic plight in the US and Europe and concerns about mass migration to Europe (Lizza 2011). Days of watching the protests spread on the streets of Egyptian cities convinced administration officials that Mubarak probably would not weather the political storm and that this was compromising the transition to a new political order (Miller 2011).

The remaining inherent contradictions of an Administration trying to simultaneously encourage and contain the forces of revolution in Egypt broke into the open on February 5, when Wisner called Mubarak an "old friend" of the United States, and said he "must stay in office in order to steer those changes through" (News Wires 2011).

Part of the confusion also stemmed from the government's own conflicting message and to the fact that the State Department diverged from the White House line. Contrary to the Iranian revolution, when the State Department had enough information "to seriously examine the possibility of profound instability for the one-man government in Iran," (David 1993, 64-65), this time around it raised doubts as to the wisdom of Mubarak's ouster. The Obama administration's awkward reaction reflects all too clearly the dilemma it faced between balancing its support for the democracy protesters' aspirations with its desire for an orderly political transition in a strategic ally. The mixed message reflected a policy seemingly wrong-footed by the speed with which the revolt mounted, and that, inevitably, was made up on the fly (Sanger 2011). Obama wanted to position the US on the side of the protesters. Simultaneously, he feared that the uprising could spin out of control and unsettle the region. He was also hard pressed to assure other autocratic allies that the US did not hastily abandon its friends. The Saudis and other "moderate" pro-US Arab states were dismayed at the manner in which the Americans had responded to a faithful ally. The US decision to forgo Mubarak shook the Saudi trust on the American hegemony. They undoubtedly do not harbor illusions about the reliability of American support under the Obama administration (Teitelbaum 2011). 
The strategic calculations behind the flip-flops of the administration are obvious: Egypt is a lynchpin of the American security architecture for the greater Middle East. As the world's largest Arab nation, Egypt is critically important to US foreign policy and to major goals the Obama administration pursues in the Middle East: the Israeli-Palestinian peace process, containment of Iran's influence and nuclear ambitions, and counter-terrorism. Egypt's role is at the heart of normalizing Arab relations with Israel. Mubarak has also helped guarantee Israel's interests and the stability of its border with Gaza. After Washington's rapprochement with Egypt, under Anwar Sadat, every US administration has invested heavily to maintain the status quo. Fear that Egypt's uprising would develop into an Islamist revolution along the lines of that of Iran in 1979 would constitute the worst possible scenario for Washington and Tel Aviv. American policymakers were initially tied by the fear that Egypt's move toward democracy might be hijacked by the Muslim Brotherhood or another group unfriendly to American interests.

But now that a generalized political upheaval swept throughout the Arab world, sticking to a status quo orientation would have been unrealistic and, political expediency-wise, negative. Eventually, the administration managed to sharpen the message and to try to place itself on the right side of history.

\section{Libya: "realigning American interests and values"}

When the revolution caught up Libya, on February 15, Obama initially resisted intervening militarily until he felt he had no choice. He preferred at first to use diplomatic means and economic sanctions to signal that Gadhafi's use of force would not help keep him in power. In the first days of the revolts, a popular criticism of the Obama administration was that its response to the Libyan crisis was sluggish, the government perceived as idling while Col. Gadhafi threatened and committed violence against his own people (Goodenough 2011). Gadhafi ignored both his own pledge of a ceasefire and the West's warning of military intervention to launch a combined air and land assault on the rebel self-declared capital of "Free Libya," Benghazi. The rebel-held city had been clinging to the hope that the Security Council-backed resolution authorizing a no-fly zone would halt his advance eastward.

The decision to intervene militarily came when Gadhafi's forces were closing in on Benghazi. On March 17, the Security Council approved resolution 1973 demanding an immediate ceasefire in Libya, including an end to the attacks against civilians, and imposing a no-fly zone - and tightened sanctions on the Gadhafi regime. Military intervention in Libya began on March 19, as Obama, who was on an official visit to Brazil, announced the beginning of the strikes, arguing: "We cannot stand idly by when a tyrant tells his people there will be no mercy" (Fox News 2011). 
The rationale for the military intervention was provided by his statement to the press: "This is the greatest opportunity to realign our interests and our values" (Hamid 2011). The president was referring to the broader change going on in the Middle East and the need to rebalance US foreign policy in order to accommodate a greater focus on democracy and human rights. He felt that, had the international community not acted when it did, thousands of Libyans would have been slaughtered as the world watched idly. As Marc Lynch noted, not acting would have been a powerful message, which would have haunted America's standing in the region (Lynch 2011).

Other factors concurred to make the intervention possible. Obama emphasized that his decision on Libya was based on what has become his foreignpolicy doctrine: relying on international consensus and multilateral action to bring about military intervention with a limited American role (Cooper 2011). In a short timeframe, Obama and Clinton managed to accomplish the following policy acts: a resolution of support for the intervention from the UN Security Council; a statement from the African Union supporting democracy in Libya; and turning over the leadership of the coalition air campaign to the NATO command in Europe so as to share the costs and dangers of the operation with allies (Davis 2011). Equally important, the administration garnered the support from the Arab League for a no-fly zone. Among Arabs, the decision enjoyed a broad consensus, among both leaders and the street.

\section{Other flashpoints: Bahrain, Yemen and Syria}

The upheaval in Bahrain, which hosts a major US military base and borders the world's primary oil producer, Saudi Arabia, is mostly rooted in discontent among the majority Shia Muslim community towards the Sunni monarchy, although instigators are also among pro-government Sunnis, and conservative factions of the ruling family (especially the Royal Court and Defense Ministers). The country is strategically located across the Persian Gulf from Iran and hosts the US Navy's Fifth Fleet. Moreover, Manama is a critical link to the decades-old US effort to protect the Western world's access to Gulf oil.

In Bahrain, where the uprisings turned violent, Obama did not even utter a word in support of armed intervention, instead pressing the regime to embrace reform on its own. Washington has moderated its regime reform pressures in Bahrain also for fears of Iranian meddling in that vital Gulf country and fear that protracted political turmoil could provide an opening for additional influence by Tehran in Bahrain's neighbor, Saudi Arabia. The intensified wrangling across the Persian Gulf between the Sunni and Shia powers has reinforced Washington's wariness about Iran's regional ambitions, strained relations between the US and important Arab allies, and tempered the former's initial support for the democracy movements in the Arab world. 
US officials are wary Bahraini Shia are susceptible to outside influences, such as attempted subversion from neighboring Iran (Hodge 2011). At the invitation of the Bahraini royal family, Saudi Arabia sent troops into Bahrain to quell the protests, a move that drove a wedge between Riyadh and Washington (Hodge 2011). Saudi Arabia fears that, if the protesters prevail, Iran - Saudi Arabia's regional rival - could expand its influence and inspire unrest elsewhere.

While the Obama administration became ever more outspoken against repression in Syria and Yemen - not to mention Libya, where Obama eventually put in practice a policy of regime change -, it remained remarkably restrained about the escalating crackdown in Bahrain. The strongest criticism came from Secretary of State Clinton in mid-April at the US-Islamic World Forum when she appealed for a "political process that advances the rights and aspirations of all the citizens of Bahrain" and asserted that "security alone cannot resolve the challenges" facing the government. She also said the administration had raised its concerns publicly and directly with Bahraini officials (Clinton 2011).

Apparently, the administration threw its weight behind attempts of Bahrain's royal family to survive, although protesters say their demands have not been met (Reuters 2012). It believes Bahrain is "an important force for political stability and economic progress in the Middle East." That is why the Defense Department announced it intends to sell US\$53 million worth of military equipment and support to the Gulf state, including armored vehicles (DSCA 2011).

In Syria and Yemen, the Obama administration took a cautious, incremental approach refraining initially from calling for a regime change. In the case of Damascus, the administration vainly held out hope for a "managed transition" before coming out and declaring Assad's rule illegitimate. Initially, Washington was skeptical that the uprising would overthrow the regime. It also believed it lacked the leverage to affect the situation in the country. There were other strategic calculi, as well, affecting the administration's appraisal: for one, Syria is critical to Obama's attempt to end Iran's nuclear program and to promote Arab-Israeli peace. Ever since it took office, Obama had been trying to engage Syria - Tehran's greatest ally in the region - to persuade Iran's leaders to end its nuclear programme and its support of anti-Israeli terrorism, if not even end its alliance with the Ayatollah's regime (Landis 2009). Finally, there was little support in the US for another military adventure in the Middle East.

As for Yemen, President Ali Abdullah Saleh's ouster posed questions about stability in a nation seen by the Obama administration as a key ally in its fight against al-Qaeda militants. As with the uprisings in Egypt and Syria, Obama initially failed to side with pro-democracy forces, wishfully choosing instead to hope for reformers among the very forces of the regime. Only much later did the tone change in regard to Yemen. The Obama administration withdrew its support two months into the uprising, after concluding that Saleh's government could not survive the revolts, and that US interests were better served by getting 
a new government in place that might pursue the fight against al-Qaeda. That issue became more urgent as al-Qaeda has been able to exploit the turmoil that has resulted from Saleh's lengthy demise, taking control of the country's lawless southern region.

Initially, the administration limited White House critiques of the regime, even after that government opened fire on demonstrators for months in a row. Tens of thousands of protesters took to the streets of the Yemeni capital in late January 2011 to demand the end of the three-decade rule of President Saleh. His departure would likely undermine, at least temporarily, US counterterrorism efforts. He was an important ally in the fight against al-Qaeda in the Arabian Peninsula, the Yemen-based group responsible for sending two parcel bombs to US synagogues in October 2010 and the attempted bombing of a Detroit-bound plane on Christmas Day 2009 (CNN 2010). Because of Saleh's cooperation, the Obama administration had been reluctant to be too critical in its comments, at least officially, or to consider publicly scenarios for his ouster.

Yemen's fragile stability increasingly became a concern to the United States as pro-democracy protests exploded into violence in mid-March. The violence, which drew condemnation from Obama and Secretary of State Clinton, may well have been the tipping point. In May, Hillary Clinton accused Saleh of turning his back on his commitments after he rejected a deal to step down (Aljazeera 2011). Clinton urged him to sign the US-backed agreement in order to prevent further chaos (Aljazeera 2011). The agreement was brokered by the Gulf Cooperation Council (GCC) under which he would hand over power within 30 days in exchange for a promise of immunity from prosecution. Despite strong Western pressure, Saleh repeatedly refused to sign the plan.

Amid rising violence, the US urged Saleh not to return home from Saudi Arabia (The Telegraph 2011) where he recovered from injuries suffered in an assassination attempt during a popular uprising in early June (ZeeNews.com 2011). Yemen fell deeper into turmoil, since the withdrawal of security forces from some provinces left a power vacuum that al-Qaeda tried to fill. Islamic militants took advantage of the chaos to seize control of several cities and towns in a southern province. On jihadist websites, the region started being referred to as the "Islamic Emirate of Abyan." That has raised American fears that the militants may establish a firmer foothold in that Arabian Peninsula country, which is close to the Saudi oil fields and overlooks key oil shipping routes (Al Bawaba News 2011). On October 21, the US co-sponsored UNSC Resolution 2014 calling for end to violence, acceptance of the Gulf Cooperation Council peace plan, and the orderly transfer of power (The White House 2011). The United States said the transfer of power in Yemen must begin "immediately" (Reuters 2010). In November 2011, Saleh signed the GCC agreement, paving the way for his vice-president to become acting president until new elections are held. 
The Obama Administration was also slow to condemn Syrian President Bashar al-Assad's violent repression of peaceful demonstrators, muting its criticism of Assad's repression. Strangely enough, only by mid-August did Obama call on Assad to resign due to the deadly crackdown on peaceful protesters. Public demonstrations across Syria began on January 26, 2011, but escalated in March.

The administration's caution with Syria is certainly due in part to the uncertainty that what follows Assad's demise might be worst. There are constraints on the US will to intervene. Assad's alliances with Iran, Hezbollah, and Hamas certainly undermine important US strategic interests in the zone, but, on the other hand, he has kept the border with Israel quiet. Another factor is the absence of the strong regional support that crystallized around Libya. Finally, there is little support in the United States for another military adventure in the Middle East.

The US slapped sanctions on Syria at the very beginning of its crackdown (The White House 2011b). Pressure to place Assad under sanctions had been building for weeks as his government continued a brutal crackdown on protesters. Until then, Obama had adopted a much more measured and cautious approach in the hope that the Syrian president would respond to international pressure. However, this approach did not work.

President Obama imposed sanctions again on May 18 against Assad himself and six top aides in order to "increase pressure on the government of Syria to end its use of violence and begin transitioning to a democratic system that ensures the universal rights of the Syrian people" (Carmichael 2011). In imposing the sanctions, the Obama administration stopped short of saying Assad had lost his legitimacy to rule, but demanded a stop to the regime's policies of repression and initiating a political transition.

Publicly calling on Assad to resign momentarily released pressure from an administration that had ruled out more risky policy options, like those pursued in Libya. For one thing, the US wanted to make sure it was acting in coordination with allies: an internationally coordinated pressure, by many capitals at once would have far more effect than one emanating from a single nation, even if that nation is the United States (Grier 2011). Obama's call for Bashar al-Assad to "step down" (Phillips 2011) was a long time coming. The president, who had spoken in public on Syria only twice, had declined to say that Assad should leave office. The Obama administration's cautious stance on the Syrian revolution put the credibility of the United States on the line, especially when it became clear, five months into the start of the uprising, that Assad's opportunity to institute real reform was not real. The other reason for dragging its feet was that Obama and Clinton had been relying on their counterparts in Turkey for advice and mediation with the Syrian regime. They expected Turkish Prime Minister Recep Tayyip Erdoğan's personal relationship with Assad might help in convincing him to pursue a reform program (Badran 2011). 
Obama's willingness to consider all options, and, especially, to cling to a "lead from behind" policy (Lizza 2011a) did not enhance American leadership (WP 2011). Eventually, the Turkish leverage over Damascus bore no fruit. In May, Turkey called on Assad to enact reforms and rein in the violent crackdown on the anti-regime protests. Assad reiterated a commitment to start a national dialogue to review new legislation, including laws on parliamentary elections, the media, and allowing political parties other than the Baath Party, as well as possible changes to the constitution (Solomon 2011). However, he has not delivered on his promises and has not implemented the reforms.

After months of stepping gingerly around urgings that Assad declaredly renounce the rule, Obama demanded that Assad step down (Lee 2011). The president's ultimatum marked a significant ratcheting up of pressure. He was accompanied by the European Union (EU) and the leaders of Britain, France and Germany also calling on Assad to leave (Lee 2011). It was a dramatic sharpening of international rhetoric since Obama, as well as other major states, had urged Assad to reform rather than resign (Oweis 2011). Relying on sanctions rather than military force, Obama has stacked a variety of sanctions against the Syrian government.

\section{Obama's "reset" speech: a new approach or same old thing?}

Speaking at the US-Islamic World Forum in March, Hillary Clinton provided some insights to clarify the US approach, stating it strongly supports democratization in the region, although rejecting a "one-size fits all approach" (Clinton 2011) to the Arab uprisings. Clinton said the administration had reoriented US policy in the Middle East to focus more on people and less on governments, but qualified that the response to the democracy movements would vary from country to country. Indeed, US policy looks different in Bahrain and Syria than it does in Libya, because American interests are very different in each arena (Clinton 2011).

The Obama administration seemed to realize the need to build a coherent policy framework towards the upheavals that dealt comprehensively with the challenges posed by this rising revolutionary wave in an area where the United States has vital interests. Obama's most comprehensive response came on May 19 in a speech at the State Department. According to analyst Friedman, Obama's speech clearly intended to be the formulation of a Middle East policy, a blueprint for policymaking, rather than just a showcase for speech-making, "reflecting a shift in strategy if not the declaration of a new doctrine" (Friedman 2011).

In that speech, he put the US as squarely standing behind the struggle for freedom and democracy, specifying that Washington supports them for all Arab peoples, not only for some (The White House 2011). Obama based US policy on core principles: opposing violence, universal rights, and the right of people to choose their own leaders. He asserted: "we can, and we will, speak out for a set of 
core principles - principles that have guided our response to the events over the past six months." However, he also reckoned the uncertainties the US faces in the process: "there will be times when our short-term interests don't align perfectly with our long-term vision for the region" (The White House 2011d).

In this context, the content and substance of Obama's speech were important, for two main reasons. First, he characterized the Arab revolts as a fight for "selfdetermination." This was a particularly significant acknowledgement of the Arab peoples' right to ultimately determine their outcome, as well as an advance on previous vacillating American responses to the uprisings. Secondly, he also made it clear that the right to live in freedom and democracy is a universal right that should be enjoyed by Bahrainis - who are strategically important to the US -, as well as by Libyans and Syrians - who are not.

Obama said the US has a historic opportunity to embrace this change and the responsibility to support the rights of people demanding for freedoms, and he announced for "a new chapter in American diplomacy." He also disclosed mainly a set of economic incentives aimed at steering the region towards lasting democratic change.

In a general sense, the speech did not really resolve the tension at the heart of the question: that between Obama's rhetoric of support for reform and the US clinging to Arab governments that are skirting reforms. Obama's speech left many observers and people in the region disappointed. He was attempting to square a difficult circle: he wanted to reaffirm America's support for democratic aspirations, but at the same time did not want to worsen a rift with allies, such as Saudi Arabia, about the pace of democratic development. Obama also said little about political grievances in Saudi Arabia, a major oil supplier, where Shia protesters have been violently dispersed. Human rights groups have called the Obama administration's approach to the so-called "Arab spring" inconsistent, charging that US policy toward some countries has a double standard (Human Rights First 2011). The speech tried to combine policy interests which are not easily reconcilable and might even produce different outcomes, at times inimical to American interests: the fact that "America's interests are not hostile to people's hopes; they're essential to them [...] and [that] we will keep our commitments to friends and partners" (The White House 2011d). Obama also acknowledged that these interests will mean that sometimes the US may not always take the most aggressive stand in favor of democracy and freedom: "There will be times when our short-term interests don't align perfectly with our long-term visions for the region, but we can and we will speak out for a set of long-term principles," the president said. The speech represented an escalation of rhetoric, but failed to adequately shift policy or even render it more coherent.

US policy towards the Arab Spring has been a divided policy marked by sincere but reactive support for democratic advances when it occurred, but no real proactive support for democracy where dictatorship remains (Carothers 2012a, 37). 
Where political change has occurred, the US has usually backed democratic change, sometimes actively, as in Libya; sometimes more reluctantly, as in Egypt. But where autocratic stability continues to reign, the administration has held fast to the decades-old US policy of support for friendly dictators who are reliable on matters of security and economics (Carothers 2012b).

It must be pointed out, however, that, in its apparent inconsistency, the administration has tried to strike the right note of "cautious optimism and seriousness of purpose" in countries undergoing a democratic transition (Carothers 2012, 34). First, it has avoided getting involved in complex internal politics of democratic transitions. The US has been cautious by avoiding to put itself in the center of internal political change, for fear of compromising the prestige of democracy advocates, of being accused of interfering, or ultimately of assuming responsibility for an yet uncertain process. Secondly, it has accepted the popular will of Arab societies even if it takes the form of Islamist electoral victories, such as in Tunisia and Egypt.

\section{Diminished US leverage}

The outcome of the current confused struggle unfolding in the Arab countries swept by the Arab Spring is of the utmost importance to American interests. Admittedly, the emergence of Islamist governments would be the more detrimental scenario to US influence, since they have anti-US platforms. Even if one assumes that democratic regimes would emerge, there is no reason to believe they will become close allies of the US. A new regional order may be emerging, one in which the leverage enjoyed by the US is shrinking and more autonomy is granted to regional actors. As Aliboni points out, "regional powers are already protagonists of a regional balance in which the West is unusually absent" (Aliboni 2011 , 9). Some new regimes, notably Egypt, may become less pro-Western than in the past and might want to reassert its role as regional leading player. The new regime might combine Islam, democracy and allegiance to Arabism, making it a more palatable model than that of its Arab pro-Western neighbors.

The central problem, as Friedman has put it, is that the widespread unrest of the Arab Spring might not turn out to be popular revolutions or that the revolutionaries necessarily want to create liberal democracies (Freedman 2011b).

The events reflect a fading Western influence in general, especially US influence. With popular uprisings sweeping through the area, US policymakers are looking at other ways Washington can stay relevant in the region. The West, not least the Obama administration, has been slow to realize the limits of their influence. They are reacting to events, not driving them. The United States is no longer able to systematically influence the choices made in the Middle East. Aliboni asserts: "the Arab spring is a transition away from the long alliance between the West and the moderate Arab states, as well as a transition of these states from being more 
or less passive clients of the US and the West to more or less vibrant democracies with an assertive agenda in the region" (Aliboni 2011,9). The administration realized that Washington's ability to steer political change in the region appears largely reduced. In Yemen and Bahrain, the leaders systematically ignored Obama administration calls to respect human rights and negotiate with the protesters. Saudi Arabia has signaled its intent to pursue foreign policy goals that, at times, might differ from US interests in the region (Gause 2011, 22). Defying US warnings, Palestinian Authority President, Mahmoud Abbas, decided to pursue a United Nations vote in September 2011 to recognize a Palestinian state.

\section{Conclusion}

It is clear that Obama decided not to take a single, blanket approach in order to avoid that rapidly-moving events drove administration policies. Events in the Middle East are part of a long-term transformation, with important risks, including the potential rise of Islamism in Egypt and potential civil war in Syria. The process will take decades to play out and will remain a challenge for the US presidents to come. The administration's answer to the Arab Spring very much reflects the interest in not being sidelined by the events and of placing itself on the "right side" of history. In the process, Obama had to juggle the idealistic and realistic impulses that have marked his foreign policy. Thus, at the beginning, an initial cautiousness was removed and the administration was driven by the emotional reaction of the street. It was only later that a policy was formulated - a policy that tries to conciliate particular US interests in the region and universal, pointedly American values.

As a result, the Obama administration's response to the Arab Spring has been fairly ambivalent, hesitant and disjointed: grudgingly supporting the uprisings in Tunisia and Egypt, unenthusiastically backing limited military action in Libya, projecting a nuanced attitude to the unrest in Bahrain, and confounding US traditional allies.

Indeed, its apparent inconsistencies (for example, calling for Hosni Mubarak's departure just days after Cairo's protests mounted, while refusing to denounce the Syria's regime, combined with a determination to a forceful regime change in Libya), only highlighted the contrast between the administration's determined approach toward some of the Arab Spring regimes and much of the rest of its Middle East policy. As for friendly countries which have weathered the storm, the Obama administration has settled on a strategy to help keep allies who are willing to reform in power, even if that means the democratic demands of their newly emboldened citizens might have to lag behind. The administration's commitment to democracy and human rights is undercut by its pursuit of countervailing economic and security interests. Growing US concern about stability in the Persian Gulf and Iran's regional influence has prompted the administration to 
largely put aside democracy priorities for the sake of good relations with strategic allies (Carothers 2012, 44).

Obama is not the only president who, as far as the democracy agenda is concerned, has demonstrated "a split personality" (Carothers 2007, 96). For decades, Washington has considered the Middle East a region of vital US interest, in part because it sits atop the world's largest reserves of oil and natural gas. To maintain its strategic influence in the region, Washington has often relied on friendly Arab governments that suppressed the democratic aspirations of their people. Like his predecessors, until the outbreak of the Arab Spring, Obama focused on building bridges with Arab leaders and governments. In improving relations with the Muslim world, there is a gap between US political ideals and the realpolitik of its strategic national interests.

The Obama administration eventually concluded that it must shape its response country by country, recognizing a stark reality that American national security interests in the Middle East weigh as heavily as idealistic impulses. The administration cautious response to the popular uprisings across the Middle East and North Africa is the reflection of a realist policy driven by strategic interests, such as oil security, fighting terrorism, Iran's rise in the region and, equally important, its realization of the limits of American power and its capacity to shape events.

\section{Bibliographic references}

\section{Primary sources}

CLINTON, Hillary R. (2011a) Secretary of State, Treaty Room, Washington, DC, Remarks with Jordanian Foreign Minister Nasser Judeh after their Meeting, 2 March, published at <http:// www.state.gov/secretary/rm/2011/01/155388.htm>. Accessed on Jan. 26, 2011.

CLINTON, Hillary R. (2011b) Secretary Clinton Delivers Remarks at US-Islamic World Forum, DipNote, 13 April, published at: <http://blogs.state.gov/index.php/site/entry/ clinton_remarks_us_islamic_forum>. Accessed on: Apr. 13, 2011.

THE WHITE HOUSE (2011a) Executive Order -Blocking Property of Certain Persons with Respect to Human Rights Abuses in Syria, 29 April.

THE WHITE HOUSE (2011b) Executive Order--Blocking Property of Senior Officials of the Government of Syria, 18 May.

THE WHITE HOUSE (2011c) Office of the Press Secretary, Remarks by the President in Address to the Nation on Libya, National Defense University, Washington, D.C., published at: <http://www.whitehouse.gov/the-press-office/2011/03/28/remarks-president-address-nationlibya>. Accessed on: Mar. 28, 2011.

THE WHITE HOUSE (2011d) Office of the Press Secretary, Remarks by the President on the Middle East and North Africa, available at: <http://www.whitehouse.gov/the-pressoffice/2011/05/19/remarks-president-middle-east-and-north-africa>. Accessed on: May 19, 2011. 
THE WHITE HOUSE (2011e) Office of the Press Secretary, White House on Passage of U.N. Resolution on Yemen, 21 October 2011.

US Department of State, Remarks with Spanish Foreign Minister Trinidad Jimenez after their Meeting, Remarks Hillary Rodham Clinton Secretary of State, January 25, 2011.

US Department of State (2011) Forum for the Future: Partnership Dialogue Panel Session, Remarks, Hillary Rodham Clinton, Secretary of State, Ritz Carlton, Doha, Qatar, 13 January, available at <http://www.state.gov/secretary/rm/2011/01/154595.htm>. Accessed on: Mar. 18, 2012.

\section{Books and reports}

BILL, James, (1988) The Eagle and the Lion: The Tragedy of American- Iranian Relations. New Haven, Conn.: Yale University Press.

BRZEZINSKI, Zbigniew (1983) Power and Principle: Memoirs of the National Security Adviser. NY: Farrar, Straus, Giroux.

CAMPBELLl, J.C. (1969) Defense of the Middle East. NY: Harper \& Row, 1969.

CAROTHERS, Thomas (2012) “Democracy Policy under Obama - Revitalization or Retreat?", CEIP, available at <http://carnegieendowment.org/files/democracy_under_obama.pdf>. Accessed on: July 17, 2012.

FRIEDMAN, George (2011a) Obama and the Arab Spring, Stratfor, available at <http://www. stratfor.com/weekly/20110523-obama-and-arab-spring>. Oct. 24, 2011.

FRIEDMAN, George (2011b) Re-Examining the Arab Spring, Stratfor, available at <http:// www.stratfor.com/weekly/20110815-re-examining-arab-spring?utm_source=freelist-f\&utm_ medium=email\&utm_campaign $=20110816 \&$ utm_term $=$ gweekly\&utm_content $=$ readmore \&elq=79d01458b68e4c7dbe0c8e266169610f>. Accessed on: Sep. 16, 2011.

GAUSE, F. G., III (2011) "Saudi Arabia in the New Middle East". Council Special Report no. 63, CFR, December.

GAUSE, F. G., III (2011) “Saudi Arabia in the New Middle East”, Council Special

LENCZOWSKI, G. (1992) American Presidents and the Middle East. Durham, NC: Duke University Press.

LESSER, Ian O. (1992) Oil, the Persian Gulf and Grand Strategy. Santa Monica, CA: RAND, 25.

PINTO, Maria do Céu (1999) Political Islam and the United States: A Study of U. S. Policy Towards the Islamist Movements in the Middle East. Reading, Ithaca Press.

SICK, Gary (1985) All Fall Down: America’s Tragic Encounter with Iran. NY: Random House.

TEITELBAUM, Joshua (2011) Saudi Arabia, Iran and America in the Wake of the Arab Spring, BESA Center Perspectives Paper No. 140, May 23, available at <http://www.biu.ac.il/SOC/ besa/docs/perspectives140.pdf >. Accessed on: June 20, 2012. 


\section{Journal articles}

ALIBONI, Roberto (2011) "The International Dimension of the Arab Spring” The International Spectator 46(4).

BADRAN, Tony (2011) “Obama's Options in Damascus”, Foreign Affairs, available at <http:// www.foreignaffairs.com/articles/68129/tony-badran/obamas-options-in-damascus?page=show $>$. Accessed on: Nov. 16, 2011.

CAROTHERS, Thomas (2007) "Debating Democracy: The Democracy Crusade Myth". The National Interest, July-August.

Carothers, Thomas (1997) “Democracy without Illusions”. Foreign Affairs (76)1.

PRESSMAN, Jeremy (2009) "Power without Influence". International Security 33(4).

\section{Internet sources}

AL BAWABA News (2011) Yemen: Al Qaeda Declares South Province as "Islamic Emirate, available at: <http:/www.albawaba.com/main-headlines/al-qaeda-declares-south-yemenprovince-islamic-emirate>. Accessed on: Mar. 31, 2011.

ALJAZEERA (2011) US Urges Yemen's Saleh To Step Down, available at: <http://english. aljazeera.net/news/middleeast/2011/05/201152381519173523.html>. Accessed on: May 23, 2011.

CARMICHAEL, Lachlan (2011) US Imposes Sanctions on Assad, Six Other Syrian Officials, available at <http://www.google.com/hostednews/afp/article/ALeqM5ijlwBpEIo1kWCd026 a84Sb0uAIfQ?docId=CNG.93d17015584f9064f404da9c7737315f.621>. Accessed on Mar. $18,2012$.

CAROTHERS, Thomas (2012) “Washington's Bow to Mideast Monarchs". WP Opinions, 4 February, available at <http://www.washingtonpost.com/opinions/obama-administrationshalf-hearted-push-for-mideast-democracy/2012/02/03/gIQAPa1znQ_story.html>. Accessed on June 30, 2012.

CBS News (2011) State of the Union: Full Obama Speech Text, available at <http://www. cbsnews.com/8301-503544_162-20029565-503544.html>. Accessed on: Jan. 25, 2011.

CNN (2010) U.S. Says al Qaeda in the Arabian Peninsula Behind Cargo Terror Plot, available at <http://articles.cnn.com/2010-10-29/world/al.qaeda.arabian.peninsula_1_yemeni-americanal-qaeda-terror-group?_s=PM:WORLD>. Accessed on: Oct. 29, 2010.

COOPER, Helene (2011) Obama Cites Limits of U.S. Role in Libya. The NYTimes, 28 March.

DAVIS, Lanny (2011) Obama-Clinton Team on Libya: Right in the Crossfire, available at The Hill, available at <http://thehill.com/opinion/columnists/lanny-davis/152903-obama-clintonteam-on-libya-right-in-the-crossfire-?tmpl=component\&page=2>. Accessed on: Mar. 30, 2011.

DSCA (2011) Bahrain - M1152A1B2 HMMWVs and TOW-2A and TOW-2B Missiles 14 September, available at <http://pomed.org/wordpress/wp-content/uploads /2011/09/ Bahrain_10-71-1.pdf Accessed on: May 15, 2012. 
DORNING, Mike and GOLDMAN, Julianna (2011) Obama Tells Mubarak Egypt's Transition to New Government 'Must Begin Now’, Bloomberg, 1 February, available at <http://www. bloomberg.com/news/2011-02-01/obama-seeks-to-support-protesters-without-repudiatingmubarak.html>.

ENTOUS, Adam and BARNES, Julien E. (2011) U.S. Wavers on 'Regime Change', The Wall Street Journal, 5 March, available at <http://online.wsj.com/article/SB100014240527487035 80004576180522653787198.html>. Accessed on: May 13, 2012.

GOODENOUGH, Patrick (2011) Criticized for Approach to Libyan Crisis, Obama Calls for Gaddafi to Step Down, available at <http://www.cnsnews.com/news/article/criticized-approachlibyan-crisis-obama-calls-gaddafi-step-down>. Accessed on: Mar. 29, 2011.

FOX News (2011) Obama Announces U.S. Airstrike on 'Tyrant' Qaddafi's Military, available at <http:/www.foxnews.com/politics/2011/03/19/obama-international-coalition-preparedact-urgency-libya/>, Mar. 19, 2011.

GRIER, Peter (2011) Why it Took so Long for Obama to Say Syria's Assad Must Go. The Christian Science Monitor, 18 August, available at <http://www.csmonitor.com/USA/ForeignPolicy/2011/0818/Why-it-took-so-long-for-Obama-to-say-Syria-s-Assad-must-go >. Accessed on: May 15, 2012.

HAMID, Shadi (2011) To Win Over Arabs, U.S. Must Go Beyond Libya. USA Today, 30 March. HODGE, Nathan (2011) U.S. Says Iran Is Meddling In Bahrain. The Wall Street Journal, 7 April, available at <http://online.wsj.com/article/SB10001424052748703280904576247230 001105602.html>. Accessed on: May 15, 2012.

Human Rights First (2011) Clinton Speech Misses Mark on Bahrain Human Rights Abuses, available at <http://www.humanrightsfirst.org/2011/04/13/clinton-speech-misses-mark-onbahrain-human-rights-abuses/>. Accessed on: Apr. 13, 2011.

LANDIS (2009). Syria Looking for Improved Relations with Obama Administration. CFR, May 15, available at <http://www.cfr.org/israel/syria-looking-improved-relations-obamaadministration/p19408>. Accessed on: May 12, 2012.

LANDLER, Mark and COOPER, Helen (2011) Obama Seeks a Course of Pragmatism in the Middle East, available at <http://www.nytimes.com/2011/03/11/world/africa/11 policy. html?_r=1>. Accessed on: Mar. 12, 2012.

LEE, Matthew (2011) US, Allies Declare That Syria's Assad Must Leave. The Huffington Post, 19 August, available at <http://www.huffingtonpost.com/huff-wires/20110818/us-us-syria/>. Accessed on: Apr. 15, 2012.

LIZZA, Ryan (2011a) Leading From Behind, The New Yorker, available at <http://www. newyorker.com/online/blogs/newsdesk/2011/04/leading-from-behind-obama-clinton. html\#ixzz1boAhic2L>. Accessed on: Apr. 27, 2011.

LIZZA, Ryan (2011b). The Consequentialist - How the Arab Spring Remade Obama's The New Yorker, available at <http://www.newyorker.com/reporting/2011/05/02/110502fa_fact_ lizza\#ixzz1M2LngelX>. Accessed on: May 2, 2011.

LYNCH, Mark (2011) Why Obama Had to Act in Libya, Foreign Policy, published at <http:// lynch.foreignpolicy.com/posts/2011/03/29/the_case_against_the_libya_intervention>.Accessed on: Mar. 29, 2011. 
MILLER, Judith (2011) American Influence Rapidly Waning in Egypt, NewsMax, available at <http://www.judithmiller.com/8713/american-influence-egypt>. Accessed on: Feb. 2, 2011.

NEWS WIRES (2011) US Envoy Says Mubarak 'Must Stay' To Steer Transition, France 24, available at <http://www.france24.com/en/20110205-us-envoy-wisner-says-mubarak-muststay-steer-transition-egypt>. Accessed on: Feb. 6, 2011.

OBAID, Nawaf (2011). Amid the Arab Spring, A U.S.-Saudi Split. The Washington Post, 16 May.

OWEIS, Khaled (2011) Obama Accuses Assad of "Slaughtering" Syrian People, Reuters, available at <http://news.yahoo.com/syria-holds-hundreds-stadium-u-n-eyes-tribunal-013129681.html>. Accessed on: Aug. 18, 2011.

PHILIPPE-DAVID, Charles (1993) Foreign Policy Failure in the White House. Lanham, MA: University Press of America.

PHILLIPS, Macon (2011). "President Obama: "The future of Syria must be determined by its people, but President Bashar al-Assad is standing in their way". May 18, available at <http:// www.whitehouse.gov/blog/2011/08/18/president-obama-future-syria-must-be-determined-itspeople-president-bashar-al-assad>. Accessed on: Jan. 30, 2012.

REUTERS, Bahrain (2012) Grand Prix to Go Ahead as Protests Flare, The WSJ, available at <http://online.wsj.com/article/SB20001424052748704832704576114340735033236.html>. Accessed on: May 15, 2012.

REUTERS (2010) Yemen's Saleh Still Must Transfer Power-White House, available at <http:// af.reuters.com/article/idAFWEN893520110930>. Accessed on: Oct. 30, 2010.

SANGER, David E. (2011) As Mubarak Digs In, U.S. Policy in Egypt Is Complicated, The NY Times, 5 February, available at <http:/www.nytimes.com/2011/02/06/world/ middleeast/06policy.html>. Accessed on: Feb. 3, 2012.

SOLOMON, Jay (2011). Syria Strongman: Time for 'Reform'. The Wall Street Journal, 31 January, available at <http://online.wsj.com/article/SB200014240527487048327045761143 40735033236.html 2011>. Accessed on: May 15, 2012.

The Telegraph (2011) US Urges Ali Abdullah Saleh not to Return to Yemen, 10 August, available at <http://www.telegraph.co.uk/news/worldnews/middleeast/yemen/8692495/US-urges-AliAbdullah-Saleh-not-to-return-to-Yemen.html>. Accessed on: May 15, 2012.

The Washington Post (2011) More Brutality in Syria and Passivity in Washington, 25 June, available at <http://www.washingtonpost.com/opinions/more-brutality-in-syria-and-passivityin-washington/2011/06/24/AGwHggjH_story.html>. Accessed on: May 15, 2012.

ZEENEWS.COM (2011) US Urges Saleh to Stay Away from Yemen, available at <http:// zeenews.india.com/news/world/saleh-vows-return-to-yemen-us-urges-him-stay-away_725320. html>. Accessed on: May 15, 2012.

World News (2011) US condemns ally Bahrain, 19 February, available at <http://www.sbs.com. au/news/article/1487236/us-condemns-ally-bahrain>. Accessed on: May 15, 2012.

Received May 4, 2012

Accepted July 18, 2012 


\begin{abstract}
When the Arab Spring broke out, the United States was in a quandary over how to handle the crisis in its attempt to balance its moral obligations and ideals without undercutting its strategic interests and those of its close allies. Flaws in US diplomatic approach have contributed to one of the most serious foreign policy crisis for a US administration to date with consequential upheaval and erosion of the US-built balance of power. The reactions and policy responses of the Obama administration highlight the difficulties in grasping with the new reality in the Middle East and in enunciating a policy platform that could combine American interests and values.
\end{abstract}

Keywords: Arab Spring; democracy; Obama administration.

\title{
Resumo
}

Quando a Primavera Árabe eclodiu, os Estados Unidos ficaram num dilema sobre como lidar com a crise tentando equilibrar as suas obrigações morais e os ideais sem fragilizar os seus interesses estratégicos e aqueles dos seus aliados mais próximos. A indecisão e as contradições na abordagem diplomática dos EUA contribuíram para avolumar uma das mais graves crises de política externa dos EUA, pondo em perigo a balança de poder que os EUA criaram na região. A reação e a resposta política da administração Obama põe em destaque a dificuldade de Washington em lidar com a nova realidade no Oriente Médio e em enunciar uma plataforma política que possa conciliar os interesses e os valores americanos.

Palavras-chave: Primavera Árabe; democracia; administração Obama. 